UDC 519.216.1

\title{
STRUCTURE ANALYSIS OF FRACTAL AND CHAOTIC COMPONENTS OF CYCLIC TRAJECTORIES FOR CONGRUENT NONLINEAR DYNAMICAL MAPS
}

\author{
G. Vostrov, A. Khrinenko \\ Odessa Polytechnic State University
}

\begin{abstract}
In this paper we consider the processes in maps, which are examples of nonlinear dynamical systems. Analyzing dynamical systems, it is necessary to take into account and analyze properties of iterative functions that determine the length of nonrepetitive iterative process. It is shown that not only properties of functions, but also properties of numbers from the considered functions domain influence the nonlinear maps behavior.
\end{abstract}

Key words: dynamical systems, nonlinear maps, randomness, trajectories, chaotic processes.

\section{Introduction}

Advancements in information theory creates an illusion that with the help of existing methods of its application it is possible to solve any problem of complex dynamic systems control for any level of their complexity. This is facilitated by the welldeveloped idea that applied problems and corresponding solution technologies do not largely depend on the level of progress in the mathematical foundations of information theory, but in reality, the number of blind spots in the theory of information theory application only increases, because actual discoveries during the studies of their trajectories rise more and more questions and there are no answers to those questions at the moment [1].

So-called blind spots include studying the structure of cyclic fixed points trajectories of nonlinear dynamical systems depending on the initial conditions. In this regard, first of all it is necessary to mathematically prove in which extent fractal and chaotic components of their trajectories and their distribution in cyclic trajectories depend on the properties of the initial conditions. In accordance to Sharkovskii's theorem [2] on the ordering of fixed points by the length of cyclic trajectories, it follows that any dynamical system having at least one cyclic fixed point with a trajectory length of three entails the existence of cyclic fixed points in this dynamic system with any length of trajectories. In general, the statement determines that this leads to the creation of so-called chaos. Solution of this problem leads us to an attempt to understand all the variety of nonlinear phenomena and processes from which our lives are woven [3].

Another area of application of ideas and methods of nonlinear dynamics is related to the problem of signal processing. Assume that a distant and inaccessible object is being studied, so the possibilities

(C) G. Vostrov, A. Khrinenko, 2021 of the study are limited by the analysis of the signal coming from it. Over the last few decades, a group of methods have been provided to determine whether this signal was generated by a dynamical system, as well as to obtain information about the properties of this system [6,7].

The aim of this work is to create a mathematical basis for the analysis of behavior and cyclic trajectories structure of complex dynamical systems, as a way to determine chaos in nonlinear stochastic dynamical systems of varying complexity. It is especially important to identify the structure of chaotic processes of cyclic fixed points trajectories over a large length, which are determined by numbers in $1 / p$ form, where $p$ is a prime number. Analysis of such trajectories is important for the reason that the structures of trajectories for the initial values $n / m$, where $n$ and $m$ are complex numbers, that may have completely different properties of cyclic trajectories for their fixed points. In the first case, based on number theory, we can analytically describe the properties of trajectories that are determined by the initial conditions with prime numbers using functional maps, which are created on the basis of group theory [8]. Entropy can be considered as a tool for measuring the complexity of trajectories. Entropy estimation methods for cyclic trajectories structure analysis of fixed points and its structure components can be considered as a process of obtaining new information about chaos in cyclic trajectories of nonlinear dynamical systems $[9,10]$.

In a general case, we can consider dynamical system models in a complex space. Regardless of the choice of sets on which models of theoretical or applied dynamical systems are built, an important problem is the choice of mathematical approach with which a mathematical model is built. It is not uncommon to use differential equations, random processes, functions of complex form, time series, which have complex forms of behavior, since its dynamical properties are almost impossible to study 
in detail by means of corresponding mathematical methods [8].

Iterations of maps on an interval into themselves are undoubtedly the simplest models, or examples, of nonlinear dynamical systems. Mathematical theory of iterative maps in general case refers to recursive functions theory, dynamical systems theory, differential equations theory and is deeply connected with the modern theory of chaos [11]. Dynamical systems use iterations of the form $x_{n} \rightarrow x_{n+1}=f\left(x_{n}\right)$, where the function $f(x)$ is defined on the interval [0;1], translates into itself and belongs to the class of primitive recursive functions [10]. Such iterative systems are the basis of methods of mathematical modeling of nonlinear processes in biology, chemistry, physics, economics, modern financial mathematics and other subject areas [12]. In general, 1-D maps are similar to each other in one form or another. Abstracting from detailed consideration, it is possible to find many common results for, at first glance, quite different maps.

A significant number of dynamical systems are modeled in continuous form using differential presentation of the form:

$$
\frac{d}{d t} x(t)=f(x(t)),
$$

where $x \in \mathbb{R}^{n}$ and $f: \mathbb{R}^{n} \rightarrow \mathbb{R}^{n}-$ a function on the phase space $\mathbb{R}^{\mathrm{n}}$. An important example of such systems are the processes of population development in an environment with certain properties. The mathematical model of such stochastic dynamical system of population development can be represented in the following Wright- Fisher form [13]:

$$
\begin{aligned}
d x_{\zeta}(t)= & c \cdot \sum_{\zeta^{\prime} \in S} q_{\zeta^{\prime} \zeta}\left(x_{\zeta^{\prime}}(t)-x_{\zeta}(t)\right) d t+ \\
+ & s \cdot x_{\zeta}(t)\left(1-x_{\zeta}(t)\right) d t+ \\
+ & \sqrt{\gamma \cdot x_{\zeta}(t)\left(1-x_{\zeta}(t)\right)} d \omega_{\zeta}(t), \\
& x_{\zeta}(0) \in[0,1] \forall \zeta \in S
\end{aligned}
$$

This equation is reduced to an iterative form which will have the following form:

$$
\begin{gathered}
x_{\zeta}(n+1)=x_{\zeta}(n)+ \\
+c \cdot \sum_{\zeta^{\prime} \in S} q(i, j)\left(x_{\zeta^{\prime}}(n)-x_{\zeta}(n)\right)+ \\
+s \cdot x_{\zeta}(n)\left(1-x_{\zeta}(n)\right)+ \\
+\sqrt{\gamma \cdot x_{\zeta}(n)\left(1-x_{\zeta}(n)\right)} \omega(n)
\end{gathered}
$$

Obtained iterative equation has a rather complex form. The behavior of such a dynamical system largely depends on the values of the constants $c, s, \gamma, S, q(i, j)$, properties of the environment $X_{\xi^{\prime}}(t)$, characteristics of genetic code change of the population $\omega_{\xi}(t)$ and its drift. As a process $\omega_{\xi}(t)$ in the Wright-Fisher model it is considered Wiener processes, such as Brownian motion or geometric Brownian motion, which is positive everywhere and has a log-normal distribution law. It is proved that in the most general form such a dynamical system is described by a random process which is a martingale. Fundamental study of cyclic fixed points and their trajectories of such dynamical systems requires possession of detailed information on the same characteristics of their components. The logistics component can be replaced by any other congruent, i.e. topologically equivalent nonlinear function. The class of such simple functions includes $\sin (\pi x)$, the square root of $\sin (\pi x)$ and the square root of logistic map due to the fact that they well approximate logistic map, however the values of such functions are irrational numbers in processes of recursive iterations. Such a set of intermediate values of recursive calculations in computer modeling processes leads to automatic rounding of intermediate values, which causes the appearance of chaotic components of another nature, which necessitates a more accurate analysis of the processes of their occurrence. Wright-Fisher model can relatively easy be adapted to dynamical processes models in stock markets, modern medicine, cloud technology analysis in semantic database theory and machine learning theory.

Thus, the study of cyclic trajectories of maps fixed points in the field of their definition, analysis of the trajectories structure in order to find selfsimilar components of a certain degree and search of their distribution laws compose a set of current mathematical problems. Another class of problems is related to the development of methods for fractal measure estimation and the formation of information in systems based on information about the structure of their cyclic trajectories.

\section{Methods of structural analysis of cyclic trajectories for nonlinear dynamical systems}

Results of dynamical systems studies depend on the properties of parameters that characterize their mapping in the form of their parameters. Systems can depend on many parameters, but the results of analysis and research of dynamical systems based on one-dimensional maps can be applied to a wide range of complex dynamical systems. Nonlinear maps of the following classes are considered: «Tent», «Asymmetric tent», «Discontinuous tent», 
«Sawtooth», «Logistic map», «Square root logistic map», «Sine map» and a «Multiplicative order map». Such choice of maps is subjected to the fact that some classes of complex maps can be considered as functions of certain combinations of these maps. In addition, between these nonlinear maps occure some dependencies that are a source of important information about the relationships between classes of primes used in discrete logarithm theory, in methods of efficient design of generators for pseudorandom sequence generation, and in number theory [6,7].

Consider «Multiplicative order map» and the basis $a$, which is greater than 1 and is not a square of a natural number. In this case, the cyclic trajectory determined by the following recursion $x_{0}=1$, $x_{n+1}=a x_{n}(\bmod p)$ can be considered as an algebraic dynamical system whose behavior on the set of prime numbers $p$ has enough complex trajectory, provided that $p$ is a large number. It should be noted that if $a$ is a primitive root of the prime number $p$ then the length of the trajectory is equal to $p-1$. In addition, each prime number according to the Euler function has corresponding number of primitive roots. Primitive root set for a given prime number $p$ allows to create recursive sequences of length $p-1$, which are permutations of one and the same set of natural numbers from 2 to $p-1$. If the value of each recursion is divided by the number $p$ then we obtain a normalized sequence of rational numbers, which in this form can be used in comparative analysis with the structures of the trajectories of other maps in the interval $(0,1)$. Given map is associated with a group of residues $(Z / p Z)^{*}$ modulo $p$. If $a-$ a primitive root of a prime number $p$, it is quite easy to prove that $a$ is a generating element of this group, and corresponding iterative process determines the permutation on the set $\{1,2,3,4, \ldots, p-1\}$, which forms a cyclic subgroup of permutations of the order $p$ for complete permutation group on this set. This simple fact is an important basis to state that such a group cannot have a chaotic structure. This statement can be demonstrated by the example of when $p=19$ and all six primitive roots $\{2,3,10,13,14,15\}$ and $\varphi(19-1)=\varphi\left(2 \cdot 3^{2}\right)$. For this set of primitive roots on the basis of iterative procedure the following permutations are received:

Table 1.

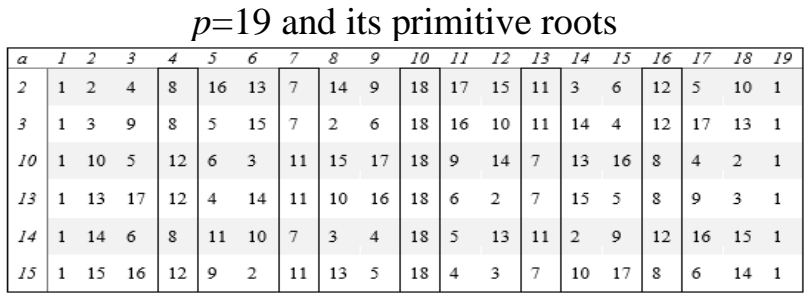

From the given example it follows that for $p=19$ a well-defined structure of permutations is traced. It is proved that for any prime number of arbitrarily large dimension on the set of all primitive roots a certain structure is formed. This structure is defined by an expansion on prime factors: $p-1=\prod_{i=1}^{k} p_{i}{ }^{a_{i}}$. In a given example $p=19$ and $p-1=2 \cdot 3^{2}$. The influence of factors 2 and 3 can be seen from Table 1. Thus, the above sequence has a well-defined structure, which does not allow to consider it as a chaotic system. Therefore, algebraic dynamical systems are reduced to a standard form, which allows you to create methods of trajectory analysis based on methods common to different mathematical forms of maps.

In work [8] it was proved that on the basis of non-normalized algebraic sequences it is possible to create a fundamental classification of prime numbers and each natural number $a$ that is not equal to $+/-1$ is a unique classifier of the set of all primes. In addition, in work [10] proved that «Symmetric tent» with the parameter $a$, which is given by the recursive function $g_{1}(x)$ under the initial condition that $x_{0}=1 / p$ creates a cyclic trajectory whose length $\operatorname{card}_{g 1}(p)$ coincides with the length of the cyclic trajectory for a prime number $p$ for «Multiplicative order map».

Consider the map $g_{3}(x)$, which has a discontinuity point, i.e. it can be considered as «Discontinuous tent» with the point $x=1 / 2$. However, the discontinuity point can take other values. In works $[13,14]$ it was proved that on the set of numbers $x_{0}=1 / p$ this map has cyclic trajectories with length $\operatorname{card}_{g 3}(1 / p)$, that in the general case does not divide $(p-1)$, despite the fact that the map can be attributed to «Discontinuous tent» class. Dynamic properties of this map indicate that the lack of information about the properties of cyclic trajectories can lead to its incorrect use in the approximation of such components of complex dynamical systems. This fact is important even when analyzing fixed points of absolute form. This is supported by the behavior of tent map at the point $x=0.666$. In the general case, the map can have a significant number of such fixed points and if their location is not taken into consideration, the lack of information about such points can lead to errors in the simulation process. These facts suggest that modeling of such dynamic systems, population development must have fairly accurate information about the properties of all components of the mathematical model. Note, that the point $\bar{x}=0.666$ does not move at all, i.e. $f^{n}(\bar{x})=f(\bar{x})$ is a fixed point of map $f$. This means that if the system reaches the point $\bar{x}$ at any moment, it will remain there. 
In paper [14] a partial set of abovementioned maps was presented and analyzed in accordance to their cyclic trajectories behavior. Control of dynamic systems that have constituent components of nonlinear type cause their difficult behavior. At the same time, it is necessary to note that in logistic map all values of iterations are rational numbers. Other maps are similar in a topological sense, however there are problems that all intermediate values are usually real numbers that are not rational numbers. In case of computer modeling intermediate values are automatically rounded, which indicates that in such cases the behavior of the dynamic system will occur with other laws whose study is relevant.

\section{Conclusion}

As a result of the analysis of various approaches to the formation of pseudorandom sequences, it was established how the choice of initial conditions affects the structure of formed sequences. If the length of the sequence period corresponds to the dimension of the selected prime number, then such a sequence is more chaotic. In contrast, it was found that under any circumstances, the existence of fixed points in the selected nonlinear dynamic system does not create chaos, but unambiguously determines the existence of a stable structure with a fixed cycle length. Applied value of these studies is that for reliable methods of pseudorandomness generation, nonlinear maps that generate sequences with fewer similar internal structures and shorter lengths of these sequences should be considered for further combination and mixing.

\section{References}

1. Balasubramanian, V., (2014). Conformal Prediction for Reliable Machine Learning: Theory, Adaptations and Applications. Elsevier.
2. Sharkovsky, A., (1988). Attractors of trajectories and their pools [Attraktory traektorij i ih bassejny]. Kyiv: «Scientific book».

3. Strogatz, S., (2018). Nonlinear Dynamics And Chaos: With Applications to Physics, Biology, Chemistry, and Engineering. CRC Press.

4. Rauch, J., (2014). Math 558. Advanced ordinany differential equations and dynamical systems: Course Materials. University of Michigan.

5. Hirsch, M., Smale, S. and Devaney, R., (2013). Differential equations, dynamical systems, and an introduction to chaos. Academic Press.

6. Manin, Yu., (2005). Introduction to Modern Number Theory. Springer.

7. Uspenskiy, V., (2009). Four algorithmic faces of randomness [Chetyre algoritmicheskikh litsa sluchaynosti]. Moscow: MCNMO.

8. Rogers, H., (1987). Theory of Recursive Functions and Effective Computability. MIT Press.

9. Lacasa, L., Luque, B., Gomez, I., (2018). On a dynamical approach to some prime number sequence. MDPI, no. 20(2), pp. 131.

10. Vostrov, G. and Khrinenko, A., (2018). Pseudorandom processes of the number sequence generation. ELTECS, no. 28(103), pp. 234-241.

11. Vostrov, G., and Yarshyn, I., (2018). Modeling of the primitive roots structure that are associated with given prime numbers. ELTECS, no. 28(103), p. 171-176.

12. Haken, H., (1983). Advanced Synergetics. Springer Berlin Heidelberg.

13. Nicolis, J., (1989). The Dynamics of Hierarchical Systems: An Evolutionary Representation. Moscow: Mir.

14. Vostrov, G., Khrinenko, A., Kolesnichenko, V., (2020). Behavior of fixed point congruent periodic trajectories of nonlinear maps in dynamical systems theory. ELTECS, no. 32(108), pp. 45-53.

\title{
АНАЛІЗ СТРУКТУР ФРАКТАЛЬНИХ ТА ХАОТИЧНИХ КОМПОНЕНТ ЦИКЛІЧНИХ ТРАЄКТОРІЙ НЕЛІНІЙНИХ КОНГРУЕНТНИХ ДИНАМІЧНИХ СИСТЕМ
}

\author{
Г. М. Востров, А. О. Хріненко \\ Держсавний університет «Одеська політехніка»
}

\begin{abstract}
Анотація. Метою даної роботи являсться створення математичних основ аналізу поведінки та структур ииклічних траєкторій складних динамічних систем, як илях до детермінації хаосу в нелінійних стохастичних динамічних системах різної міри складності. Особливо важливо виявити структуру хаотичних прочесів траєкторій циклічних нерухомих точок над великої довжини, які визначаються числами щсо мають вигляд 1/p, де р-просте число. Аналіз таких траєкторій важливий по тій причині, щзо структури траєкторій для початкових значень $\mathrm{n} / \mathrm{m}$, де $n$ та $\mathrm{m}$ являються складними числами, може мати зовсім інші властивості циклічних траєкторій нерухомих точок. При цьому в першому випадку на основі теорії чисел можна аналітично описувати властивості траєкторій які визначаються початковими умовами з простими числами за допомогою функиіональних відображень, які створюються на основі теорії груп. Інструментом міри складності траєкторій
\end{abstract}


можна вважати ентропію. Методи обчислення різниці між ентропією до аналізу структури циклічних траєкторій нерухомих точок та ентропією після виділення їі структури можна розглядати як процес отримання нової інформачї стосовно хаосу в ииклічних траєкторіях нелінійних динамічних систем. Математична теорія ітерачійних відображень в загальному випадку відноситься до теорії рекурсивних функиій, теорії динамічних систем, теорії диференційних рівнянь та глибоко пов'язана $з$ сучасною теорією хаосу. Показано, що динамічні системи можуть залежати від багатьох параметрів та мати складну математичну форму, проте ї̈ можнна представити як функиію від певної множини відносно простих відображень, які являються моделями відносно простих динамічних систем. Між приведеними відображеннями у роботs існують залежності, які являються джерелом важливої інформачї стосовно взаємодії між їхніми ииклічними траєкторіями нерухомих точок при початкових умовах х(0)=1/p та класами простих чисел, які використовуються в теоріі дискретного логарифма, в методах побудови ефективних генераторів псевдовипадкових чисел та в самій теорії чисел.

Ключові слова: динамічні системи, відображення, випадковість, траєкторії, хаотичні прочеси.

\title{
АНАЛИЗ СТРУКТУР ФРАКТАЛЬНЫХ И ХАОТИЧЕСКИХ КОМПОНЕНТ ЦИКЛИЧЕСКИХ ТРАЕКТОРИЙ НЕЛИНЕЙНЫХ КОНГРУЭНТНЫХ ДИНАМИЧЕСКИХ СИСТЕМ
}

\author{
Г. Н. Востров, А. О. Хриненко \\ Государственный университет «Одесская политехника»
}

\begin{abstract}
Аннотация. В данной работе рассмотрены процессы в нелинейных отображениях, которые являются примерами динамических систем. Анализируя динамические системы, важно принимать во внимание и анализировать свойства итерационных функиий, которые определяют длину итерационного прочесса. Показано, что не только свойства функиий, а и свойства чисел из области определения функиий влияют на поведение нелинейных отображений.
\end{abstract}

Ключевые слова: динамические системы, отображения, случайность, траектории, хаотические прочессы.

Received on 18.04.2021

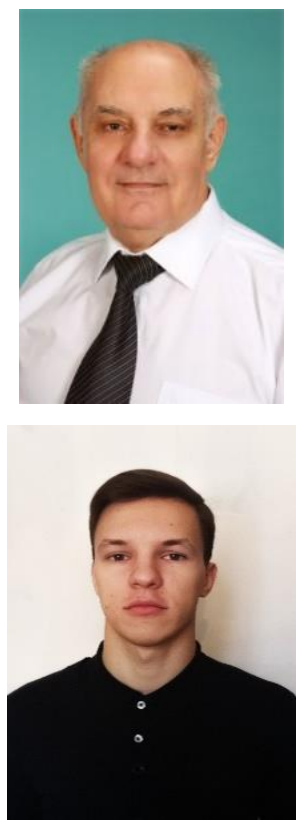

George Vostrov, Odessa Polytechnic State University, Ph. D. of Technical Sciences, Associate Professor of the Department of Applied Mathematics and Information Technologies. Shevchenko ave., 1, Odessa, Ukraine.

E-mail: vostrov@gmail.com, тел. +380503168776

Востров Георгій Миколайович, Державний університет «Одеська політехніка», кандидат технічних наук, доцент кафедри прикладної математики та інформаційних технологій. Проспект Шевченко, 1, Одеса, Україна.

E-mail: vostrov@gmail.com, тел. +380503168776

ORCID ID: 0000-0003-3856-5392

Khrinenko Andrii, Odessa Polytechnic State University, Ph.D. student of the Department of Applied Mathematics and Information Technologies. Shevchenko ave., 1, Odessa, Ukraine.

E-mail: khrinenko.andrew@gmail.com, тел. +380637515228

Хріненко Андрій Олегович, Державний університет «Одеська політехніка», аспірант кафедри прикладної математики та інформаційних технологій. Проспект Шевченко, 1, Одеса, Україна.

E-mail: khrinenko.andrew@gmail.com, тел. +380637515228

ORCID ID: 0000-0001-6000-2102 